\title{
The Potential of Micro-hydro Power Cascade in Irrigation Channel of Kalibawang, Indonesia
}

\author{
Masrur Alatas a,, , Maria Theresia Sri Budiastuti ${ }^{\text {, }}$, Totok Gunawan ${ }^{\mathrm{c}}$, Prabang Setyono ${ }^{\mathrm{d}}$ \\ ${ }^{a}$ Department of Environmental Science, Graduate School of Sebelas Maret University, Central Java, Indonesia \\ ${ }^{b}$ Department of Agrotechnology, Faculty of Agriculture, Sebelas Maret University, Central Java, Indonesia \\ ${ }^{c}$ Faculty of Geography, Universitas Gadjah Mada, Yogyakarta, Indonesia \\ ${ }^{d}$ Department of Biological Science, Sebelas Maret University, Surakarta 57126, Central Java, Indonesia \\ Corresponding author: "masruralatas@ity.ac.id
}

\begin{abstract}
Indonesia's program and regulation on the national New and Renewable Energy Policy mix target are at least $23 \%$ by 2025 and $31 \%$ by 2050 to increase the role of NRE to energy security and self-sufficiency in energy. The government's plan Energy sourced from hydropower, mini micro-hydro installed $20,960 \mathrm{MW}$ in 2030 and $45,379 \mathrm{MW}$ in 2050. The construction of dams on the river can have an impact on the backwater and the environment. Construction of micro-hydro in existing irrigation channels is an environmentally friendly solution. In this study, Identification of Potential Head $(\Delta H)$ in Irrigation Channels used an unmanned aerial vehicle (UAV) DJI Phantom 4. DEM data processing was to produce contours at 7 potential micro-hydro location points. Data Flow Duration Curve (FDC) determined the mainstay discharge of $5 \mathrm{~m} 3 / \mathrm{s}$ with a probability of $85 \%$. Discharge analysis from secondary irrigation data for 11 years (2009-2019). The results of this study found the Head potential P1 $\Delta H 15 \mathrm{~m} 625 \mathrm{~kW}, \mathrm{P2} \Delta \mathrm{H} 1.5 \mathrm{~m} 63 \mathrm{~kW}$, P3 $\Delta$ H $5 \mathrm{~m} 208 \mathrm{~kW}$, P4 $\Delta$ H $3 \mathrm{~m} 125 \mathrm{~kW}$, P5 $\Delta$ H $8 \mathrm{~m} \mathrm{333kW,} \mathrm{P6} \Delta$ H $7 \mathrm{~m} 291 \mathrm{~kW}$, P7 $\Delta H 3.5 \mathrm{~m} 146 \mathrm{~kW}$ and total micro-hydro potential along Kalibawang irrigation channel reaches 1.8 MW. Special Result found the Microhydro Blumbang-Kedungrong Cascade (P5-P6) $\Delta H 15 \mathrm{~m} 600 \mathrm{~kW}$ with proposed Kaplan turbine S-Type and service area to increase from 135 to 720 homes in 2 sub-districts.
\end{abstract}

Keywords - Unmanned aerial vehicle (UAV); Micro-hydro cascade; irrigation channel; micro-hydro development.

\section{INTRODUCTION}

The population growth in Indonesia from 2007 to 2017 was at $1.24 \%$ per year. The growth was in the economic and industrial fields. The energy growth in Indonesia rate of $8.15 \%$ per year until 2030 [1]. Petroleum production in Indonesia is only up to 12 years. Natural Gas production is estimated up to 33 years, while Coal is estimated up to 82 years [2]. To anticipate the depletion of fossil fuels and efforts to anticipate climate change in Indonesia, the national energy mix, which was originally in 2015, namely fossil energy by $95 \%$ and new and renewable energy with the energy conversion of $5 \%$, increased to the target of the 2025 new and renewable energy up to $23 \%$ and in 2050 the new and renewable energy is expected to reach $31 \%$ [2]. Until the end of 2019, the total renewables installed capacity on-grid and off the grid is 10.17 GW, with $385 \mathrm{MW}$ of new capacity added. Hydropower still dominates with $5.4 \mathrm{GW}$, geothermal at $2.13 \mathrm{GW}$, bioenergy at $1.9 \mathrm{GW}$, mini/micro hydro at $464.7 \mathrm{MW}$, solar PV at 152.4
MW, waste power plant at 15.7 MW, and wind at 148.5 MW [3]. In the household sector during 2018-2050, the energy demand for the household sector is estimated to increase by an average of $3.2 \%$ to 350.7 million BOE in 2050. Electrical energy is estimated to dominate this sector with a share of around $58 \%$ in 2050 [4]. Fossil energy production the declining, especially crude oil and the global commitment in reducing greenhouse gas emission. Indonesia government through Government Regulation No. 79 of 2014 on National NRE Policy mix target is at least $23 \%$ by 2025 and $31 \%$ by 2050 for to increase the role of NRE continuously to maintain energy security and self-sufficient in energy [4]. Hydroelectric Power is a power plant applying power from flow or waterfalls, reservoirs, dams, or irrigation channels whose construction is multipurpose with a capacity of less than $1 \mathrm{MW}$, between $1 \mathrm{MW}$ to $10 \mathrm{MW}$, and greater than 10 MW. Classification of hydroelectric power plants based on power generation capacity (MW) (Table 1). Indonesia is located on the equator and, mountainous areas, high rainfall is a hydro (Pico, Micro, Medium and Large Hydropower). the 
utilization of micro-hydro power energy for electricity generation is low, only $1 \%$ of the total potential of 19,385 $\mathrm{GW}$ in Indonesia [5].

The micro hydropower process is energy conversion. Weir is a hydraulic structure on a natural river, the weir concentrating the water head level and then guiding the high water level to the low-position turbine through the water channel (Penstock or Draft Tube). The water energy is converted into rotational mechanical energy, turbine, and generator to generate electricity. The conversion is from water energy to electricity [6].

A weir is a construction in the river, water block and divides water distributed to the agricultural areas. Weir of multifunction hydropower with irrigation system, control the amount of water distributed to irrigation channel by using the sluice gates [7]. This is important to provide excellent management of water resources for irrigation and hydropower.

TABLE I

CLASSIFICATION OF HYDRO POWER STATIONS

\begin{tabular}{clllc}
\hline No & \multicolumn{1}{c}{ Classification } & Indonesia & Malaysia & Egypt \\
\hline 1 & Large & HPS $>10 \mathrm{MW}$ & $>100 \mathrm{MW}$ & $>100 \mathrm{MW}$ \\
2 & Medium & & $10-100 \mathrm{MW}$ & $10-100 \mathrm{MW}$ \\
3 & Small & $1-10 \mathrm{MW}$ & $1-10 \mathrm{MW}$ & $<10 \mathrm{MW}$ \\
4 & Mini & $<1 \mathrm{MW}$ & $100 \mathrm{~kW}-1 \mathrm{MW}$ & $100-1000 \mathrm{KW}$ \\
5 & Micro-hydro & - & $5 \mathrm{~kW}-100 \mathrm{~kW}$ & $10 \mathrm{MW}$ \\
6 & Picohydro & $<5 \mathrm{~kW}$ & $<1 \mathrm{KW}-100 \mathrm{KW}$ \\
\hline
\end{tabular}

The main consideration in developing micro-hydro is due to a stable flow and high difference (head). The stable flow rate needs to be considered because it affects the turbine's rotational speed [12]. At the same time, the head is important for calculating the power that can be generated and estimating the type of turbine that is good to be applied [13]. Kalibawang irrigation channel has a stable discharge potential (Q) for micro-hydropower plants. This study aims to identify the potential of micro-hydro in the Kalibawang irrigation channel based on an information technology Drone or An unmanned aerial vehicle (UAV).

\section{MATERIALS AND Methods}

\section{A. Study Area}

Progo River Basin passes through two provinces, namely Central Java and the Special Region of Yogyakarta (DIY), including Temanggung, Magelang, and Kulonprogo Regencies (Figure 1). The area of Progo River Basin reaches $2,421 \mathrm{~km} 2$, with the length of the main river reaching $138 \mathrm{~km}$. Kalibawang Irrigation Area is planned with a discharge of 7000 liters / second with intake from the side tap in Progo River.

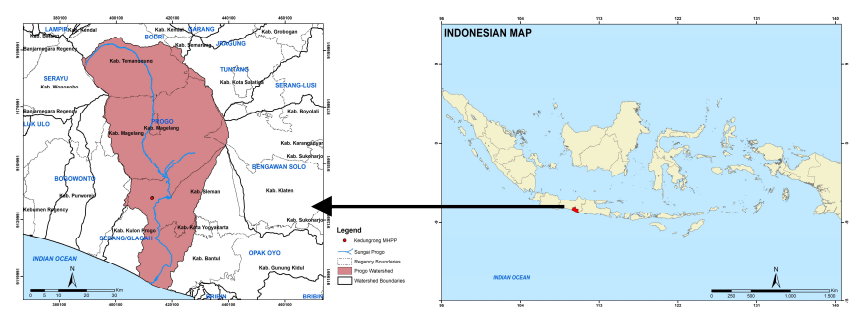

Fig. 1 Map of study location

Fig. 1 shows the field study location in the special region of Yogyakarta, Indonesia. Fig. 2 shows the river basin's field study location in Kalibawang, under a fairly steep foothill, and is an area of the Menoreh Hills. Hilly conditions and steep topographical conditions indicate a potential for a fall or (head). The hilly conditions allow grid-based electricity supply to experience constraints for economic and technical reasons [14], [15]. For this reason, the development of power plants themselves needs to be done. The slope is one of the important factors in the construction of hydroelectric power plants and the availability of water to drive turbines. Adhau et al. [16] state that the greater the head, the more energy that can be generated. Kalibawang Irrigation Area has an area of 7,152 ha. There are seven potential drop points in the primary irrigation channel in Kalibawang Irrigation System for microhydro plants. The potential points are determined based on consideration of the height of the contour from the UAV measurement results. Potential points are presented in Fig. 2. Point 1 is located at $0+5.8 \mathrm{Km}$ from intake, Point 2 at $0+6$ $\mathrm{Km}$, Point 3 at $0+9.1 \mathrm{Km}$, Point 4 at $0+9.8 \mathrm{Km}$, Point 5 at $0+12.9 \mathrm{Km}$, Point 6 at $0+13.5 \mathrm{Km}$, and Point 7 at $0+21$ $\mathrm{Km}$.

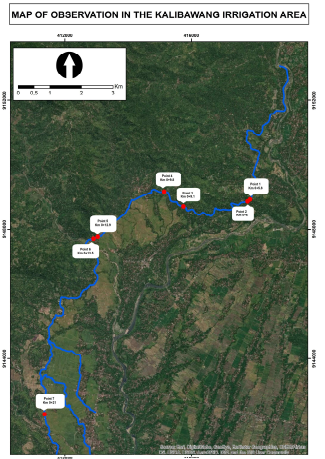

(a)

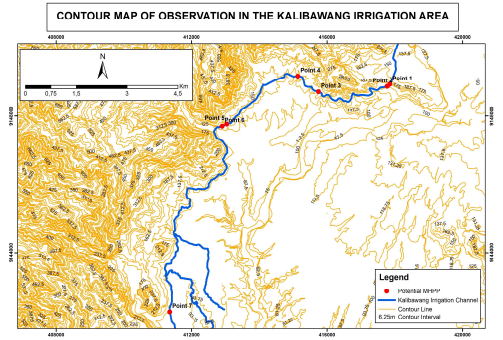

(b)
Fig. 2 Map of observation locations (a) and contours (b) in the Kalibawang irrigation area

\section{B. Data Collection}

The techniques were to identify micro-hydro potential, data and map collection (field study locations, irrigation connection, location of potential points), image photographs, hydrological data (rainfall, discharge), and contours. Hydrological data were obtained from secondary data from 2009 to 2019. The data of irrigation canal intake was applied for 11 years to produce hydrographs and Flow Duration Curve (FDC). The mainstay discharge data and the height difference were the main parameters of micro-hydro potential. 


\section{Data Processing}

UAV will be efficient and effective if between Human (piloted) understanding machine UAV, the situation, environment, and methods operational for control system and target detection accuracy [17]. Unmanned Aerial Vehicles (UAVs) can be used for engineering survey works close-range mapping. Generally, a conventional survey involves high costs, huge labor, and much time. Low-cost UAVs are very practical in providing reliable information for many applications [18]. Most studies survey possible parcel points using ground surveys with total stations. Compared with ground surveys. UAV Data comprehensively combines digitalized cadastral maps with the collection parcel points UAV aerial photogrammetry and can provide more parcel points [19].

Collecting data photographic images and DEM data in areas with high vegetation rates and low costs could use UAV [20], data capture used DJI Phantom 4 drones to produce high data resolution [21]. Alatas et al. explained that UAV measurements were required to prepare the desired flight path and map output scale. The flight path was measured based on the grid model using Pix4D Capture software, while the height of the flight was adjusted to the map output scale between 50-75 meters using the formula in equation (1):

$$
\mathrm{S}=\mathrm{CFL} /(\mathrm{HF} 2 \text { - HG1) }
$$

Note: $\mathrm{S}=$ Scale, $\mathrm{C}_{\mathrm{FL}}=$ Camera Focus Length, $\mathrm{HF}_{2}=$ Flying Height above Object (Drone), $\mathrm{HG}_{1}=$ Ground Level levation

High-resolution DEM data could be generated from aerial photographs [22], and was used to identify topography to produce head values (difference in water level between upstream and downstream channels), using the formula in equation (2):

$$
\Delta \mathrm{H}=\mathrm{H}_{\mathrm{UWL}}-\mathrm{H}_{\mathrm{LWL}}
$$

Note: $H_{U W L}=$ Upper Water Level, $H_{L W L}=$ Lower Water Level

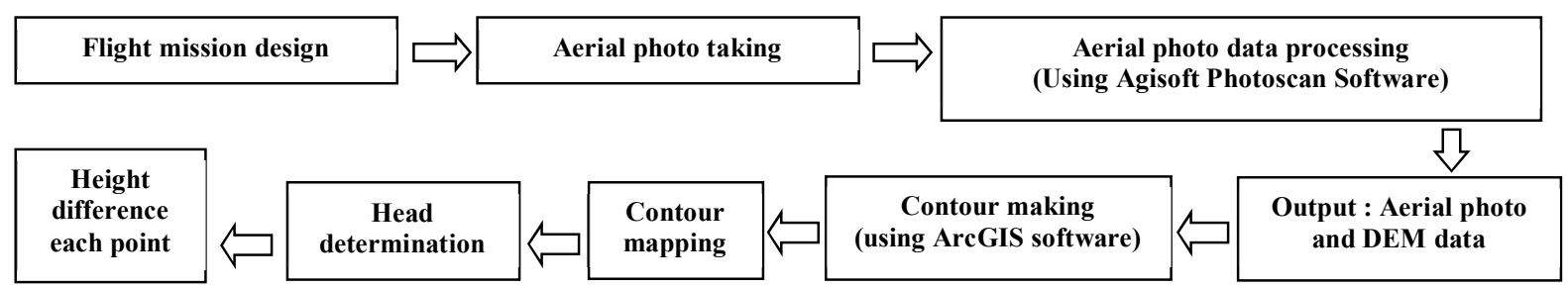

Fig. 3 The Scheme of Height Measurement (head) using UAV data

The UAV-based height difference flow chart was presented in Fig. 3. Taking photos started with the determination of the flight path and flight altitude. The aerial photography results were mixed (mosaics) with a series of processes as follows: Build Dense Cloud, Build Mesh, Build Texture, Build DEM, and Build Orthomosaic. The contouring of the ArcGIS software could be adjusted to the desired contour interval (CI) to produce a detailed head. Height difference $(\Delta \mathrm{H})$ resulted from the reduction of the water surface of the upstream part of the channel with the downstream channel. In short, the Drone produced photos with coordinates. Then it was processed in the form of the point cloud (xyz data of RGB citizens) and then processed into DEM, then from DEM data to contour, the difference in contour interval could be known as the height difference $(\Delta \mathrm{H})$ of micro-hydro drop potential.

The determination of the discharge data used to determine the type of turbine was calculated based on the Curved Duration (FDC) with a probability of $85 \%$. Meanwhile, the energy potential was calculated using equation (3).

$$
\mathrm{P}=\rho \times \mathrm{g} \times \mathrm{H} \times \mathrm{Q} \times \eta_{\mathrm{r}}
$$

Note. : $\mathrm{P}=$ power, $\rho=$ specific weight, $\mathrm{g}=$ gravity, $\mathrm{H}=$ height difference (head), $Q=$ flow rate, $\eta_{\mathrm{r}}=$ efficiency ratio

\section{Data Analysis}

1) Rainfall Data : Fig. 4a shows a rain map using the isohyet method. $1,2,3,4$ points were in the rain range 2161 $2407 \mathrm{~mm} /$ year; point 5, 6 were in the range of rain 1916$2161 \mathrm{~mm} /$ year; while point 7 was in the lowest rainfall range of 1423-1670 mm / year. The development of hydroelectric power plants was very dependent on the level of rainfall and water availability, so rain data were an important parameter
[23]. Catchment Area management was very important to realize sustainable micro-hydro.

2) River Progo Discharge and Kalibawang Irrigation Channel Hydrograph: The average discharge of Progo River was around $58.50 \mathrm{~m}^{3} / \mathrm{s}$. A river flows throughout the year. Fig. $4 \mathrm{~b}$ showed the rain duration curve showing that more than 60 inches of rainfall could be guaranteed for both $75 \%$ and $85 \%$ probability. This condition was- suitably possible to build micro-hydro [16]. Fig. 4c was a hydrograph of intake discharge data, with a reliable discharge of $50 \%, 75 \%$, and $90 \%$. Mainstay discharge for a $50 \%$ probability was consistent at $6 \mathrm{~m} 3 / \mathrm{s}$, while for a $75 \%$ and $90 \%$ probability, there was a decrease from May to June.

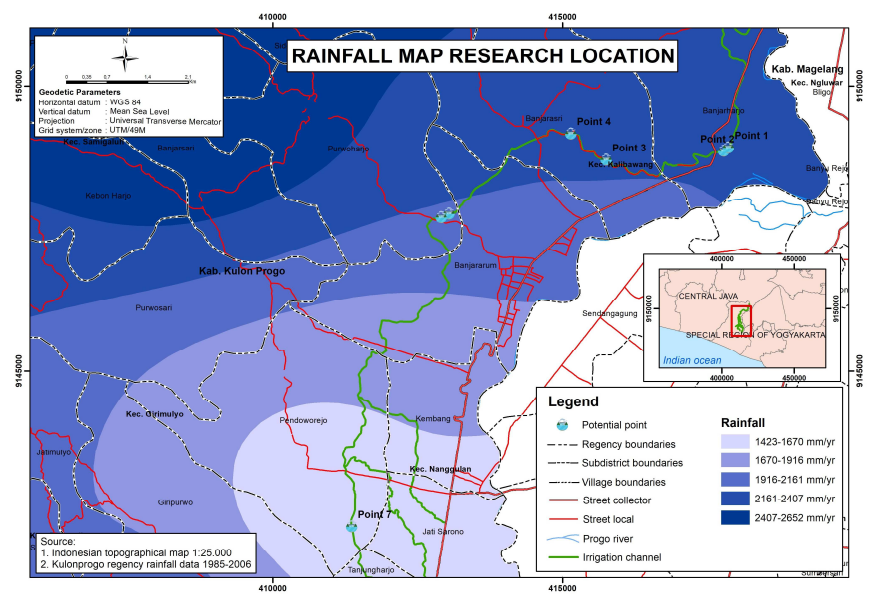

(a) 


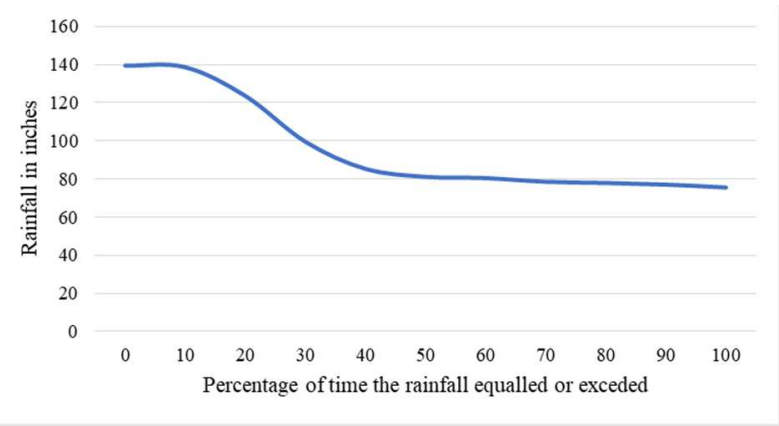

(b)

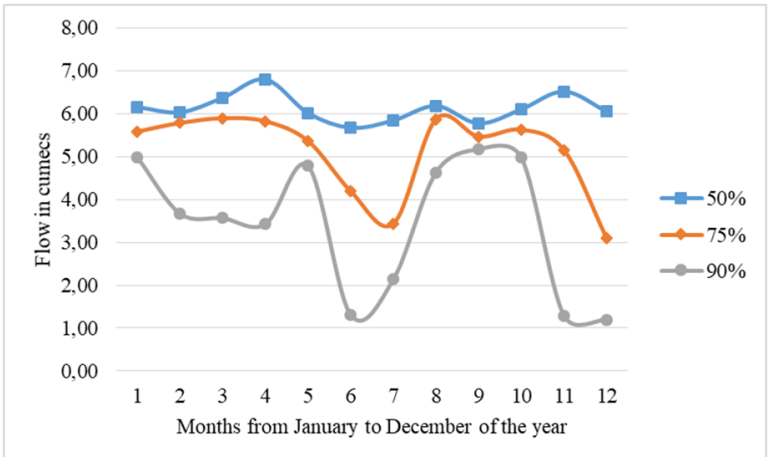

(c)

Fig. 4 (a) Rain map at the field study location (b) Rain duration starch, (c).Mainstay discharge

Fig. 5 was a monthly hydrograph of intake discharge for 11 years (2009-2020).

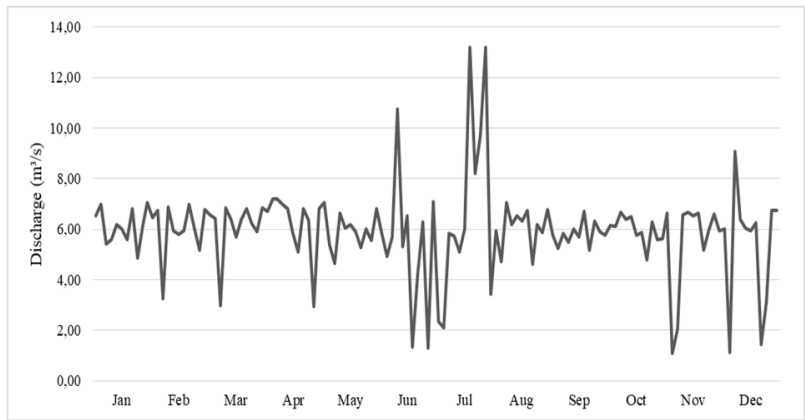

Fig. 5 Hydrograph Irrigation Channel, average maximum discharge on JulyAgustus, in the dry season, the rice fields need a lot of water to irrigate the rice fields.

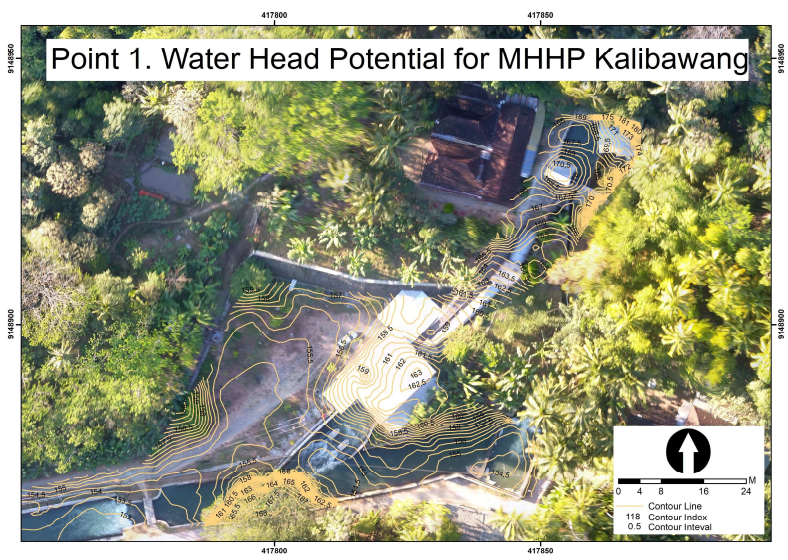

(a)
3) Kalibawang Irrigation Area Intake Data Discharge: Flow Duration Curve (FDC) is a method utilized to graphically describe the relationships between the frequency and magnitude of the streamflow. FDC is an essential tool for hydroelectric power plant planning [24]. Prententage Q FDC every country is different from Austria, Italy, Slovenia, and Romania recommendation and found that Q 95\% for FDC is even higher than established by each respective state law [25]. FDC is used to get a series of daily discharges at the study site [26]. Fig. 6 shows the mainstay discharge FCD of $5 \mathrm{~m}^{3} / \mathrm{s}$ with a probability of $85 \%$. The higher the flow rate, the equal or greater the smaller the probability.

4) Data discharge Intake Kalibawang primary channel and mainstay discharge: The maximum discharge was 13.21 $\mathrm{m} 3 / \mathrm{s}$. The average discharge was $6.02 \mathrm{~m} 3 / \mathrm{s}$, and the probability $(85 \%)$ of the measured discharge was $5 \mathrm{~m}^{3} / \mathrm{s}$. Based on the flow duration curve data, the development of the Cascade Kulonprogo micro-hydro with a probability of $85 \%$ with a discharge of $5 \mathrm{~m}^{3} / \mathrm{s}$ can generate $600 \mathrm{~kW}$ of energy.

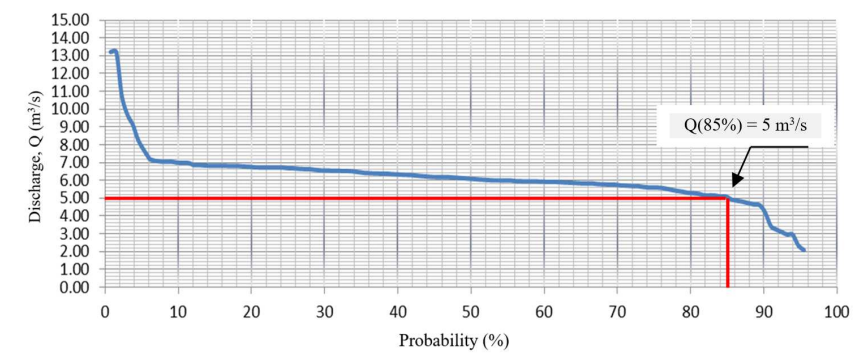

Fig. 6 Flow duration curve

\section{RESULT AND DISCUSSION}

\section{A. 7-point Potential Head based on UAV Measurement}

Retrieval of data by UAV produced aerial photographs and dem which was then used to obtain contour data, presented in Fig. 7-8. The difference between the upper water level and the water after falling was the head $(\Delta \mathrm{H})$. Point $1 \Delta \mathrm{H} 15 \mathrm{~m}$ was in line with the existing conditions in the development of microhydro. Point $2 \Delta \mathrm{H} 1.5 \mathrm{~m}$ with P $63 \mathrm{~kW}$, point $3 \Delta \mathrm{H} 5 \mathrm{~m}$ with $\mathrm{P}$ $208 \mathrm{~kW}$, point $4 \Delta \mathrm{H} 3 \mathrm{~m}$ with $\mathrm{P} 125 \mathrm{~kW}$. Points 5 and $6, \Delta \mathrm{H}$ are $3 \mathrm{~m}$ high and $\Delta \mathrm{H} 8 \mathrm{~m}$, with $\mathrm{P} 334 \mathrm{~kW}$ and $292 \mathrm{~kW}$. Point $7 \Delta \mathrm{H}$ $3.5 \mathrm{~m}$ with $\mathrm{P} 146 \mathrm{~kW}$.

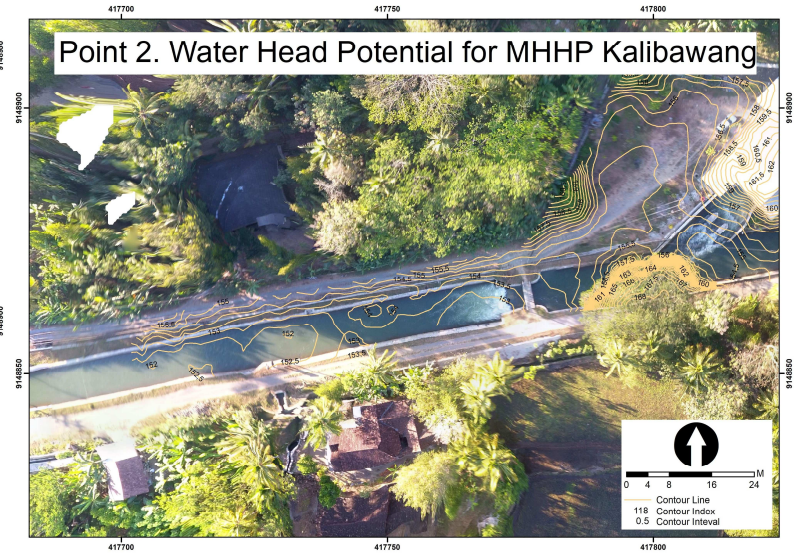

(b) 


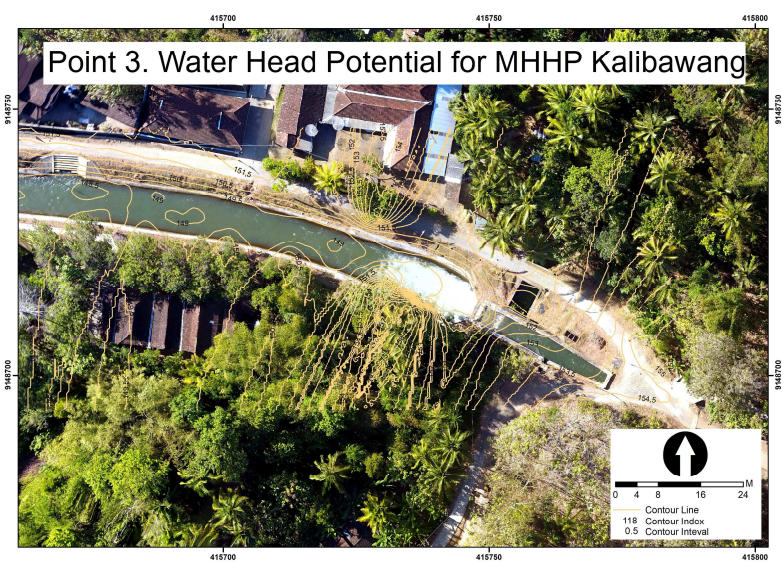

(c)

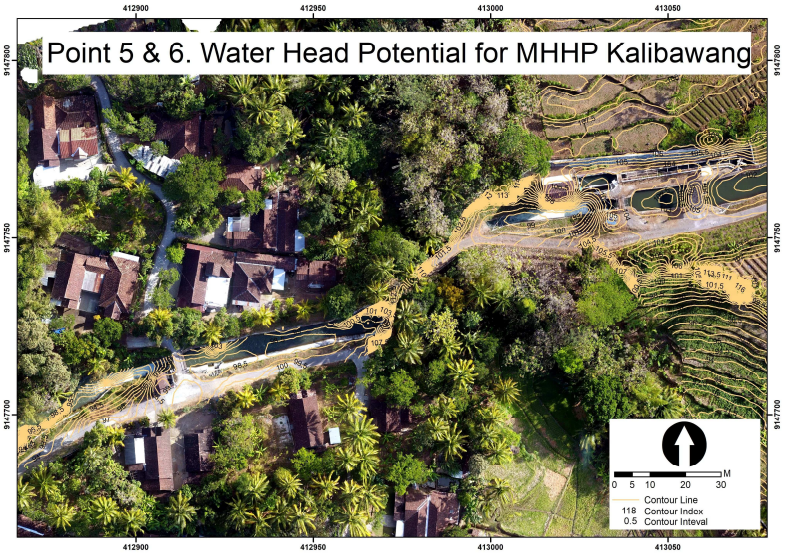

(e)

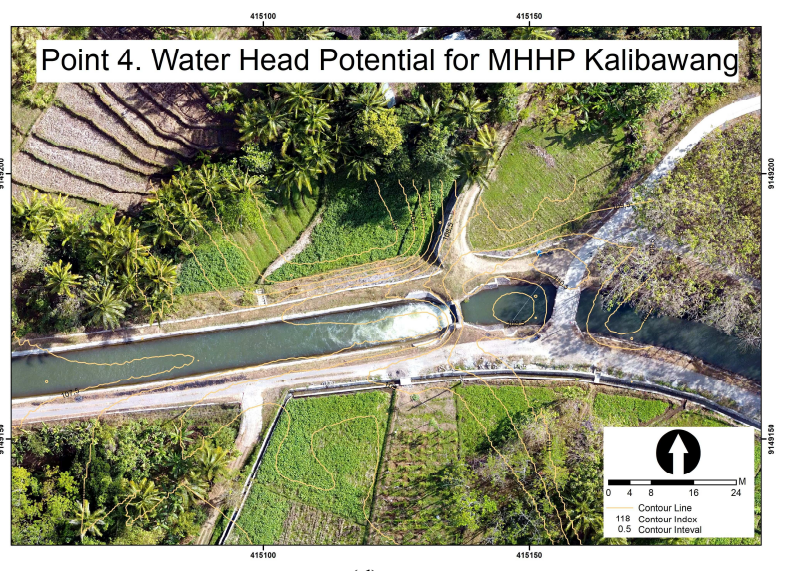

(d)

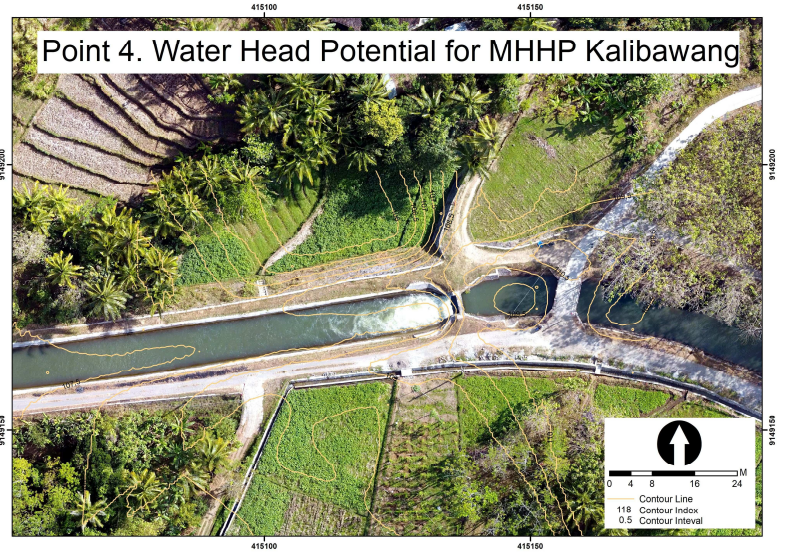

(f)

Fig. 7 (a-f). UAV image for each point with water level information based on contour (a) Point 1, (b) Point 2, (c) Point 3, (d) Point 4, (e) Point 5 and 6, (f) Point

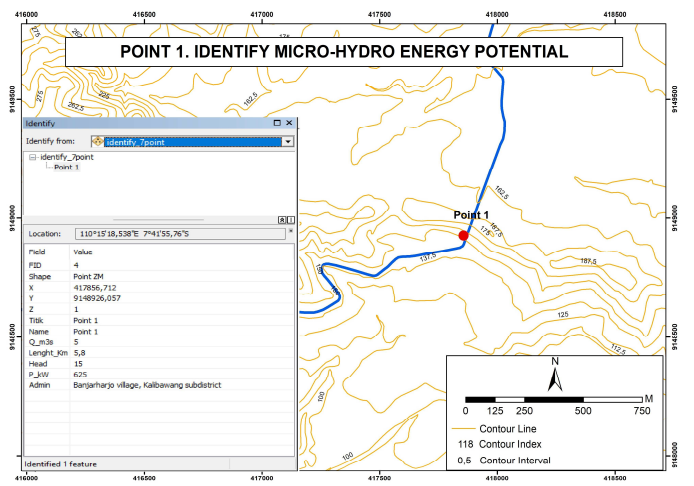

(a)

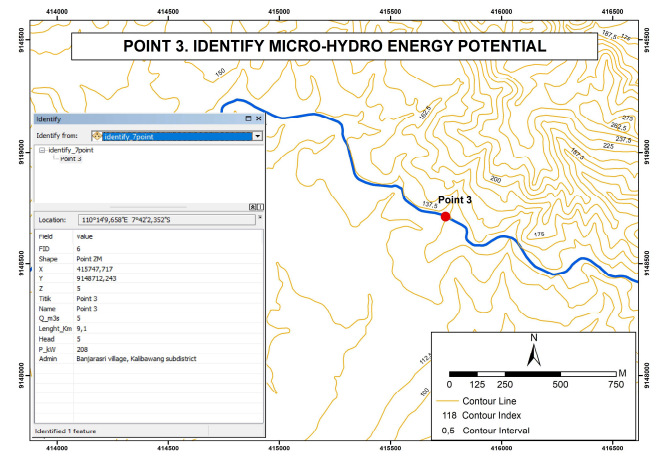

(c)

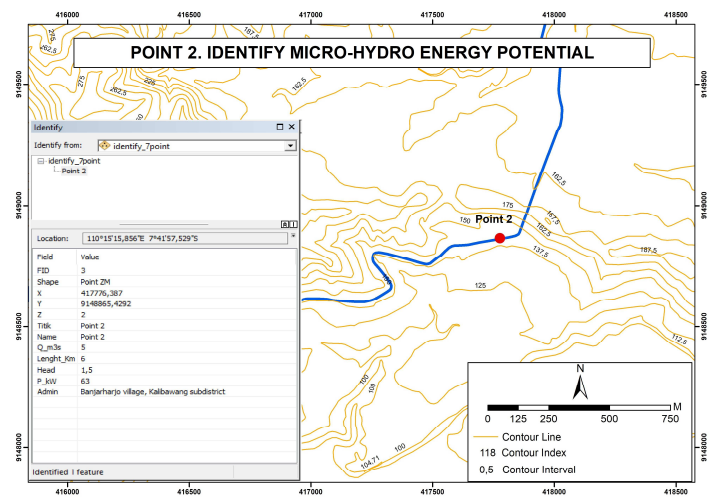

(b)

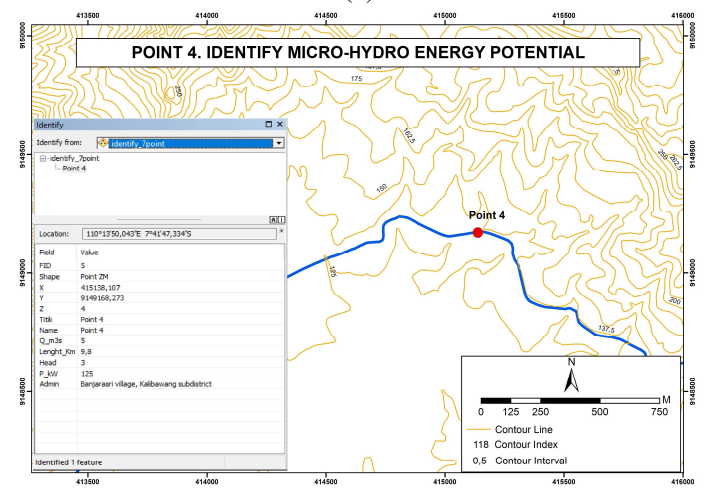

(d) 


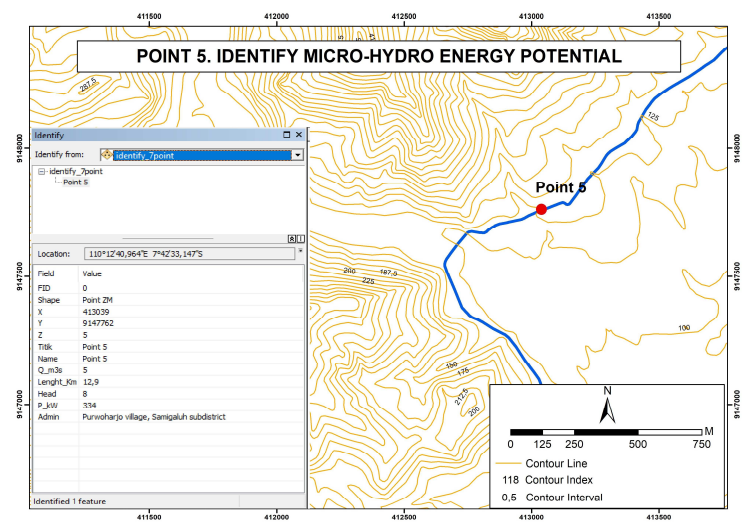

(e)

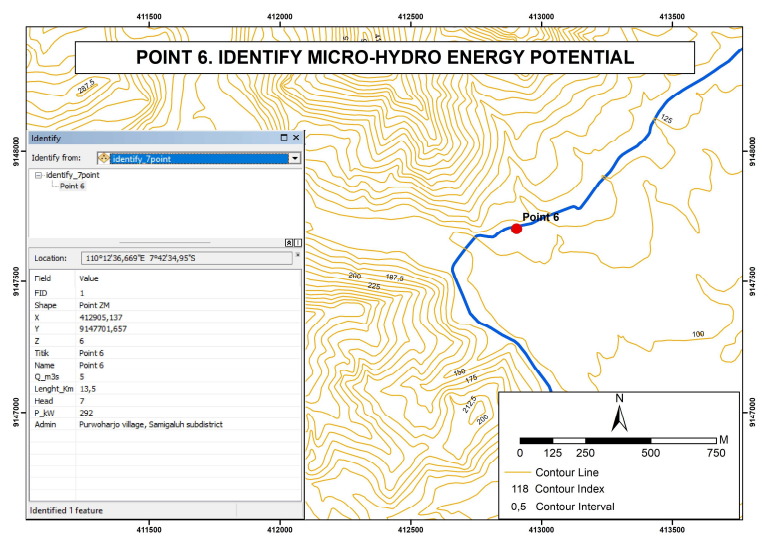

(f)

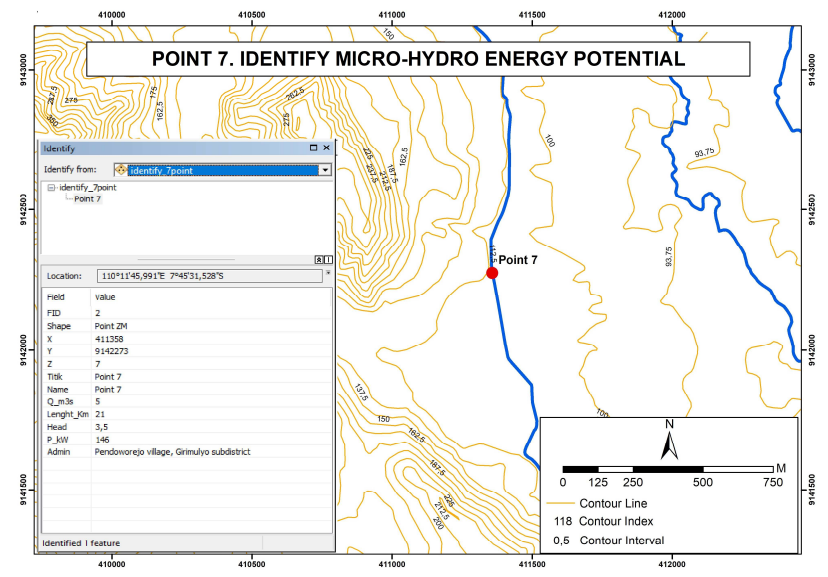

(g)

Fig. 8 (a-g). Contour map at each point, (a) Point 1, (b) Point 2, (c) Point 3, (d) Point 4, (e) Point 5, (f) Poin 6, and (g) Point 7.

The discovery of the potential micro-hydro cascade combined from points 5 and 6 could still be raised again with a discharge of $5 \mathrm{~m}^{3} / \mathrm{s}$ with a production of $600 \mathrm{~kW}$ without having to disrupt the existing micro-hydro. The type of turbine is recommended depending on the discharge characteristics and the height difference (head) [27]. Operating head classification of hydro-turbines, turbine type reaction for head low $(<10 \mathrm{~m})$ is Francis (Open Flume), Propeller, and Kaplan Turbine [10]. In this study, turbine recommendations were determined using graphs [9], presented in Fig. 9.

\section{B. New Assessable-Raised Potential Micro-hydro}

Table 2 showed the potential micro-hydro plan that could be built to make it more profitable. Micro-hydro development around points 5 and 6 was done because there was still a channel discharge that was just passed over. This meant that utilization of the channel discharge was not yet optimal for micro-hydro in the area, so further studies were needed to develop new micro-hydro. The plan at points 5 and 6 was to develop a micro-hydro system by taking a channel discharge of $5 \mathrm{~m} 3 / \mathrm{s}$ and $15 \mathrm{~m}$ to obtain a power potential of $600 \mathrm{~kW}$. And if all the potential was utilized, the total $P$ was $1,840 \mathrm{~kW}$ or $1.8 \mathrm{MW}$.

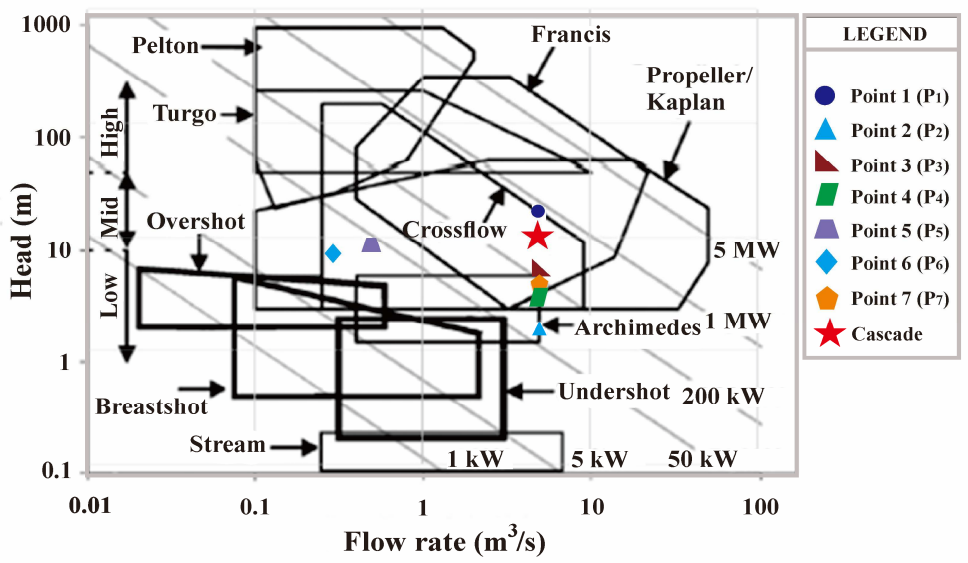

Fig. 9 Graph for turbine recommendations. Adapted from [9], [28] 
TABLE II

MICRO-HYDRO ENERGY POTENTIAL

\begin{tabular}{|c|c|c|c|c|c|c|c|c|}
\hline \multirow{2}{*}{ Point } & \multicolumn{2}{|c|}{ Coordinate } & \multirow{2}{*}{$\begin{array}{c}\text { Flow rate } \\
\text { (Q) } \\
\mathrm{m}^{3} / \mathrm{s}\end{array}$} & \multirow{2}{*}{$\begin{array}{c}\text { Gross Head } \\
(\Delta \mathrm{H}) \\
M \\
\end{array}$} & \multirow[t]{2}{*}{$\eta$} & \multirow{2}{*}{$\begin{array}{c}\text { Power (P) } \\
\text { kW } \\
\end{array}$} & \multirow[t]{2}{*}{ Info } & \multirow{2}{*}{$\begin{array}{c}\text { Turbine } \\
\text { Recommend } \\
\text { Types } \\
\end{array}$} \\
\hline & $\mathbf{X}$ & $\mathbf{Y}$ & & & & & & \\
\hline P1 & 417857 & 9148926 & 5 & 15 & $85 \%$ & 625,0 & Existing on grid & Existing Kaplan \\
\hline $\mathrm{P} 2$ & 417776 & 9148866 & 5 & 1.5 & $85 \%$ & 63,5 & Proposed & Archimedes \\
\hline P3 & 415748 & 9148712 & 5 & 5 & $85 \%$ & 208,5 & Proposed & Archimedes \\
\hline $\mathrm{P} 4$ & 415138 & 9149168 & 5 & 3 & $85 \%$ & 125,1 & Proposed & Archimedes \\
\hline P5 & 413039 & 9147762 & 0,5 & 8 & $85 \%$ & 33,4 & Existing off grid & Open flume \\
\hline P5 & 413039 & 9147762 & 4,5 & 8 & $85 \%$ & 300,2 & Proposed & Open flume \\
\hline P6 & 412905 & 9147702 & 0,5 & 7 & $85 \%$ & 29,2 & Existing off grid & Open flume \\
\hline P6 & 412905 & 9147702 & 4,5 & 7 & $85 \%$ & 262,6 & Proposed & Open flume \\
\hline P7 & 411358 & 9142273 & 5 & 3.5 & $85 \%$ & 145,9 & Proposed & Archimedes \\
\hline Total & & & & & & 1.793 & & \\
\hline
\end{tabular}

Source: modified from [21]

C. Development of Micro-hydro Cascade Kulonprogo 600 kW (status: proposed) (Points 5 and 6)

Development of potential points 5 and 6 was for microhydro Cascade to optimize potential with a production capacity of $600 \mathrm{~kW}$, Q design $5 \mathrm{~m}^{3} / \mathrm{s}$ FDC probability of $85 \%$, penstock pipe length $\pm 200 \mathrm{~m}, \varnothing 1.79 \mathrm{~m}$, Kaplan S-Type recommendations (Fig. 9).

D. Sustainable Irrigation Water Management for Existing Micro-hydro and Micro-hydro Cascade Kulonprogo Development

The results of the irrigation channel discharge analysis of 7 $\mathrm{m}^{3} / \mathrm{s}$, with average data processing, discharge from 2009 to
2019 obtained $6.02 \mathrm{~m}^{3} / \mathrm{s}$, based on the FDC, the Cascade micro-hydro design discharge with a design discharge of 5 $\mathrm{m}^{3} / \mathrm{s}$ by combining head point 5 and point 6 . Blumbang and Kedungrong micro-hydro periodically require a $0.5 \mathrm{~m}^{3} / \mathrm{s}$ discharge, so that with an average irrigation channel of $6 \mathrm{~m}^{3} / \mathrm{s}$, it could meet the needs for two existing micro-hydro and a new proposed micro-hydro cascade (Fig. 10). The planning of the penstock must pay attention to water hammer pressure, cavitation and erosion. Therefore, protection devices like pressure relief valves, surge tanks, intake gates, air chambers, air valves, load and flow control such as turbine wicket gates, spillway, and penstock control valves [29].

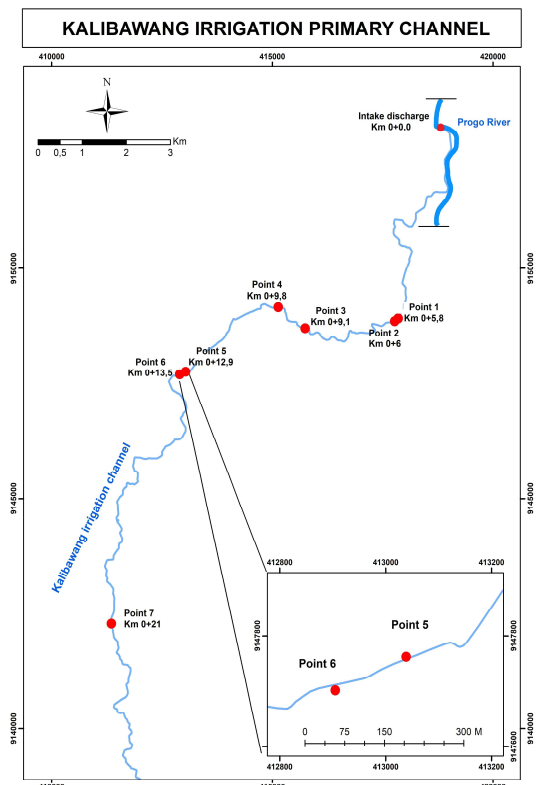

(a)

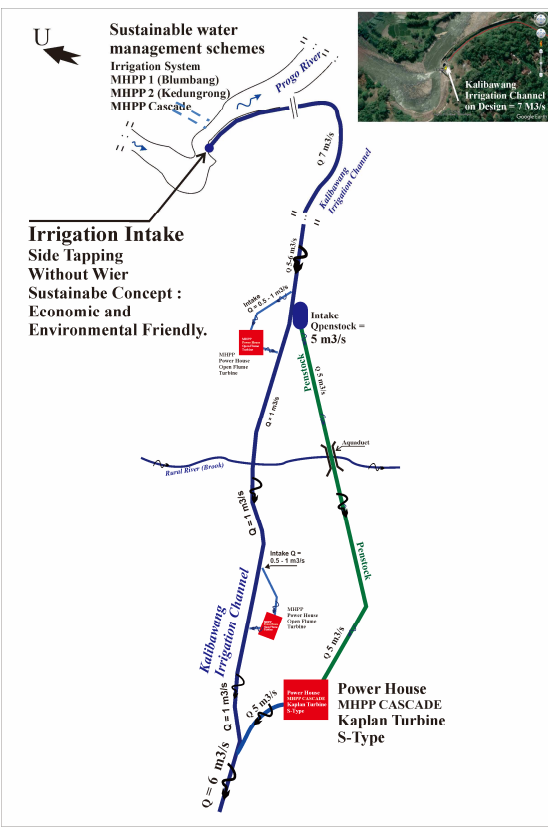

(b)

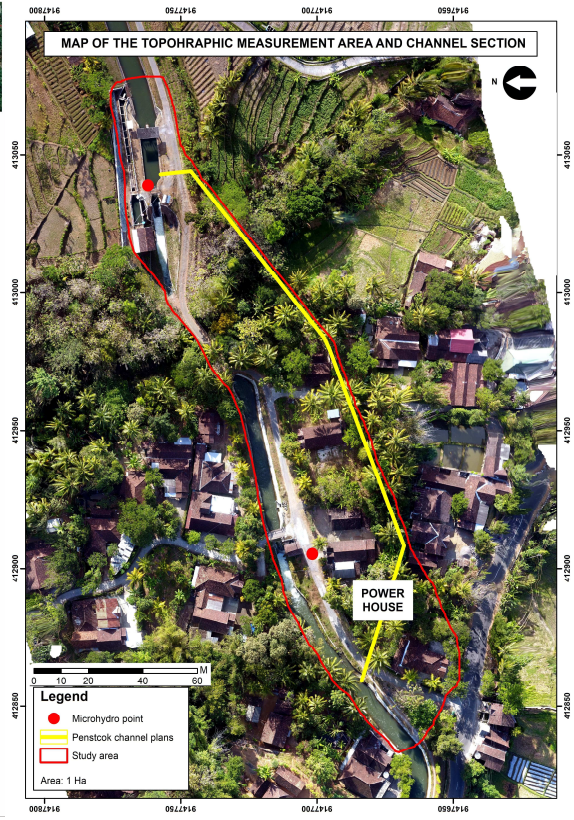

(c)

Fig. 10 Cascade hydro (a) Seven points of micro-hydro potential, (b) water management scheme for sustainable micro-hydro, (c) penstock channel BlumbangKedungrong Microhydro Cascade $600 \mathrm{~kW}$

The proposed development of a micro-hydro cascade could be utilized for further maintenance and management from points 5 and 6 . With considerable energy potential, electricity generated from a micro-hydro cascade could be sold to the electricity company to contribute to the availability of regional electricity and income for the sustainability of the micro-hydro that had been built.

\section{E. Micro-hydro Development and Management}

Expanding the study into more rural areas investigates the sustainability of MHPs and the potential at location development. Tariff and benefit for financial viability and sustainability development system. Development of microhydro identifies potential, design, and opportunities to 
introduce technology reliability of micro-hydro [30]. Development of cascade micro-point potential 5 and 6, with the benefit of two hamlets, was in Kedungrong Hamlet, Purwoharjo Village Samigaluh District as many as 35 houses and 100 houses Blumbang Hamlet, Banjararum Village, Kalibawang Subdistrict. Based on field findings, the Cascade

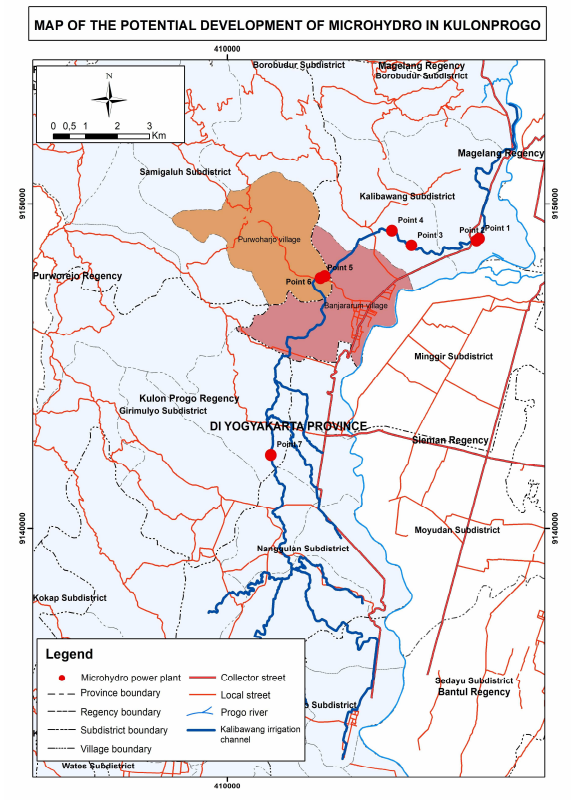

(a) micro-hydro with a potential of $600 \mathrm{~kW}$ was planned to meet the needs of 666 homes with 900 watts/house. Fig. 11 showed the current electricity distribution map and the construction of the Cascade micro-hydro that could distribute electricity to two districts, namely Samigaluh District and Kalibawang District.

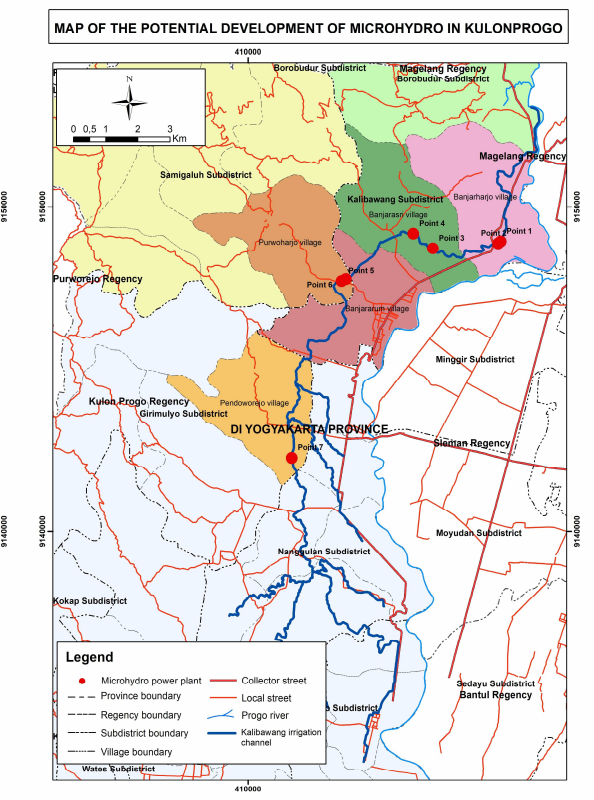

(b)

Fig. 11 Graphic development of the distribution of existing micro-hydro users and future development Electricity (a) distribution in 2012-2020), (b) (Development of new electricity)

TABLE III

RESEARCH DISCOVERY

\begin{tabular}{|c|c|c|c|c|}
\hline No & Parameters & $\begin{array}{c}\text { Existing micro-hydro } \\
(30 \mathrm{~kW}+18 \mathrm{~kW})\end{array}$ & $\begin{array}{c}\text { Potential cascade } \\
(600 \mathrm{~kW})\end{array}$ & $\begin{array}{c}\text { Existing micro-hydro + cascade } \\
(648 \mathrm{~kW})\end{array}$ \\
\hline 1. & Water resource optimization & $17 \%$ & $92 \%$ & $92 \%$ \\
\hline 2. & Electricity & 135 houses & 666 houses & 720 houses \\
\hline \multirow[t]{11}{*}{3.} & The area is electrified & Hamlet \& village level : & Two sub-district & Three sub-district \\
\hline & & Purwoharjo Village & Samigaluh sub-district & Samigaluh sub-district \\
\hline & & Banjararum Village & Kalibawang sub-district & Kalibawang sub-district \\
\hline & & & Four villages & Girimulyo sub-district \\
\hline & & & Purwoharjo Village & Five Villages : \\
\hline & & & Banjararum Village & Purwoharjo Village \\
\hline & & & Banjarasri Village & Banjararum Village \\
\hline & & & Banjarharjo Village & Pendoworejo Village \\
\hline & & & & Banjarasri Village \\
\hline & & & & Banjarharjo Village \\
\hline & Power/house & 300-500 Volt Ampere & increased to 900 Volt Ampere & increased to 900 Volt Ampere \\
\hline
\end{tabular}

Based on Table 3, the findings showed that the addition of the potential of micro-hydro cascade as a top priority for the development of micro-hydro, the distribution of electricity users could reach five times more, from 135 houses to 720 houses. The energy generated for each house originally only $450 \mathrm{VA} /$ house increased to $900 \mathrm{VA} /$ house, reaching two times greater. Determination of 900 watts of energy for each home started with complaints from users stating that $450 \mathrm{VA}$ of power could only be used for lighting purposes. So that electricity needed for home industries that used large electric power could be handled after the addition of power. Ngowi et al. also showed that access to electricity leads to business productivity in Bulongwa, Tanzania [31]. In micro-hydro management, government involvement is the key to the longterm sustainability of micro-hydro [32]. The micro hydropower plant has the lowest minimum payback period of about 1 to 6 years [33]. 
TABLE IV

Comparison Data of The CASCAde Blumbang Kedungrong Micro Hydro with Other EXisting Micro Hydro (Kaplan S-TyPe Turbines)

\begin{tabular}{|c|c|c|c|c|}
\hline \multirow[b]{2}{*}{ No } & \multirow[b]{2}{*}{ Information } & \multicolumn{3}{|c|}{ Title Hydropower } \\
\hline & & $\begin{array}{l}\text { MHP Blumbang-Kedungrong Cascade } \\
\text { (The Proposed Findings) }\end{array}$ & $\begin{array}{l}\text { MHP Lodagung } \\
\text { (existing) }\end{array}$ & MHP Semawung (Existing) \\
\hline 1 & Location & Blumbang Kedungrong, Yogyakarta & Wlingi Blitar, Jawa Timur & Semawung, Yogyakarta \\
\hline 2 & System & $\begin{array}{l}\text { Proposed / Planning Off Gride } \\
\text { (Community - Semi Businnes }\end{array}$ & $\begin{array}{l}\text { Microhydro Existing On Grid } \\
\text { PT. Jasa Tirta Energi (Businnes) }\end{array}$ & Microhydro Existing On Grid \\
\hline 3 & Condition/status & Proposed / Planning & Running & Running \\
\hline 4 & Discharge & $\pm 5 \mathrm{~m}^{3} / \mathrm{s}$ (Scenario water management) & $3.96 \mathrm{~m}^{3} / \mathrm{s}-6 \mathrm{~m}^{3} / \mathrm{s}$ & $5 \mathrm{~m}^{3} / \mathrm{s}$ \\
\hline 5 & Head gross & $\pm 15 \mathrm{~m}$ (UAV - DEM Data) & $12.5 \mathrm{~m}$ & $\pm 15 \mathrm{~m}$ \\
\hline 6 & Efisiensi & $\overline{85} \%$ & $90 \%$ & $\overline{85} \%$ \\
\hline 7 & Power Out & $+600 \mathrm{~kW}$ & $650 \mathrm{~kW}$ & $625 \mathrm{~kW}$ \\
\hline 8 & Unit System & $\overline{1}$ Unit x $600 \mathrm{~kW}$ & 2 unit $\times 650 \mathrm{~kW}$ & $625 \mathrm{~kW}$ \\
\hline 9 & Pipe length & $\pm 200 \mathrm{~m}$ & $+410.46 \mathrm{~m}$ & $\pm 35 \mathrm{~m}$ \\
\hline 10 & Type of Turbine & 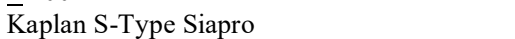 & 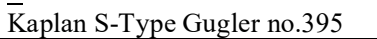 & Kaplan S-Type \\
\hline
\end{tabular}

\section{CONCLUSIONS}

The total micro-hydro potential that could be developed in Kalibawang Irrigation Channel, Kulonprogo from Point 1-7 and cascade reached 1.8 MW. The point that had been built (existing) only produces energy of $673 \mathrm{~kW}$. Proposed findings and development of a Microhydro Blumbang-Kedungrong Cascade at points 5 and 6 can add electrical energy of $600 \mathrm{~kW}$, with a potential $\mathrm{H}$ value of $15 \mathrm{~m}$, Q design of $5 \mathrm{~m}^{3} / \mathrm{s}$, the turbine recommendation is Kaplan S-Type and can improve the distribution of electrical energy for more than 666 homes. Combined existing and the new micro-hydro cascade would produce $648 \mathrm{~kW}$, serve 720 houses, and increase micro-hydro consumer power from $450 \mathrm{VA}$ up to $900 \mathrm{VA}$. This microhydro cascade would increase production, power energy and expand micro-hydro energy services in two sub-districts. An open opportunity for further research is the feasibility of investment economic analysis and a Trashrack system for diverting organic and inorganic waste and processing system waste from irrigation canals.

\section{ACKNOWLEDGMENT}

The authors are grateful to Universitas Sebelas Maret (UNS) and Gadjah Mada University (UGM). The authors are also obliged to Purwoharjo Village-Owned Enterprises, Jasa Tirta Energi (JTE), Mineral Resources Energy of Yogyakarta Province, Kulonprogo Regency Water Resources Office, Indonesian Research and Training Institute, Indonesian Integrated Micro Hydro Community (KMTI) Kulonprogo, and all research team.

\section{REFERENCES}

[1] Center of Assessment for Process and Energy Industry, Indonesia Energy Outlook 2018. Sustainable Energy for Land Transportation. Jakarta: Center of Assessment for Process and Energy Industry, Agency for the Assessment and Application of Technology, 2018.

[2] Presiden Republik Indonesia, Peraturan Presiden Republik Indonesia Nomor 22 Tahun 2017 tentang Rencana Umum Energi Nasional. Indonesia, 2017.

[3] IESR, "Indonesia Clean Energy Outlook: Tracking Progress and Review of Clean Energy Development in Indonesia," Jakarta: Institute for Essential Services Reform (IESR). Institute for Essential Services Reform (IESR), Jakarta, 2019, [Online]. Available: www.iesr.or.id.

[4] Secretariat General National Energy Council, "Indonesia Energy Outlook 2019," National Energy Council. National Energy Council, Jakarta, 2019, [Online]. Available: https://www.esdm.go.id/assets/media/content/content-indonesiaenergy-outlook-2019-english-version.pdf.
[5] D. Hadiyanto, Y. A. Purwanto, B. P. Noorachmat, and A. Sapei, “An Indicator and Evaluation Criteria for Off-Grid Micro-Hydro Power Sustainability Assessment," Int. J. Renew. Energy Res., vol. 9, no. 3, 2019.

[6] A. Q. Tian, S. C. Chu, J. S. Pan, H. Cui, and W. M. Zheng, "Article A Compact Pigeon-Inspired Optimization for Maximum Short-Term Generation Mode in Cascade Hydroelectric Power Station," Sustainability, vol. 12, no. 767, 2020, doi: 10.3390/su12030767.

[7] B. Suntaranont, S. Aramkul, M. Kaewmoracharoen, and P. Champrasert, "Water Irrigation Decision Support System for Practical Weir Adjustment Using Artificial Intelligence and Machine Learning Techniques," Sustainability, vol. 12, no. 1763, 2020, doi: 10.3390/su12051763.

[8] J. Hanafi and A. Riman, "Life Cycle Assessment of a Mini Hydro Power Plant in Indonesia : A Case Study in Karai River," Procedia CIRP, vol. 29, pp. 444-449, 2015, doi: 10.1016/j.procir.2015.02.160.

[9] A. Kadier, M. S. Kalil, M. Pudukudy, H. A. Hasan, A. Mohamed, and A. A. Hamid, "Pico hydropower ( PHP ) development in Malaysia : Potential, present status, barriers and future perspectives," Renew. Sustain. Energy Rev., vol. 81, pp. 2796-2805, 2018, doi: 10.1016/j.rser.2017.06.084.

[10] A. Y. Hatata, M. M. El-Saadawi, and S. Saad, "A feasibility study of small hydro power for selected locations in Egypt," Energy Strateg. Rev., vol. 24, no. April 2018, pp. 300-313, 2019, doi: 10.1016/j.esr.2019.04.013.

[11] M. Rotilio, C. Marchionni, and P. D. Berardinis, "The Small-Scale Hydropower Plants in Sites of Environmental Value: An Italian Case Study," Sustainability, vol. 9, no. 2211, 2017, doi: 10.3390/su9122211.

[12] B. Guo, S. Bacha, M. Alamir, A. Mohamed, and C. Boudinet, "LADRC applied to variable speed micro-hydro plants: Experimental validation," Control Eng. Pract., vol. 85, no. March 2018, pp. 290298, 2019, doi: 10.1016/j.conengprac.2019.02.008.

[13] C. P. Jawahar and P. A. Michael, "A review on turbines for micro hydro power plant," Renew. Sustain. Energy Rev., vol. 72, no. January, pp. 882-887, 2017, doi: 10.1016/j.rser.2017.01.133.

[14] S. Choudhury, A. Parida, R. M. Pant, and S. Chatterjee, "GIS augmented computational intelligence technique for rural cluster electrification through prioritized site selection of micro-hydro power generation system," Renew. Energy, vol. 142, pp. 487-496, 2019, doi: 10.1016/j.renene.2019.04.125.

[15] M. Kamran, R. Asghar, M. Mudassar, and M. I. Abid, "Designing and economic aspects of run-of-canal based micro-hydro system on Balloki-Sulaimanki Link Canal-I for remote villages in Punjab, Pakistan," Renew. Energy, vol. 141, pp. 76-87, 2019, doi: 10.1016/j.renene.2019.03.126

[16] S. P. Adhau, R. M. Moharil, and P. G. Adhau, "Reassessment of Irrigation Potential for Micro Hydro Power Generation," IEEE ICSET, 2010.

[17] Z. R. Mahayuddin, H. M. Jais, and H. Arshad, "Comparison of human pilot (remote) control systems in multirotor unmanned aerial vehicle navigation," Int. J. Adv. Sci. Eng. Inf. Technol., vol. 7, no. 1, pp. 132138, 2017, doi: 10.18517/ijaseit.7.1.1789.

[18] M. A. Zulkipli and K. N. Tahar, "Multirotor UAV-Based Photogrammetric Mapping for Road Design," Int. J. Opt., 2018, doi: $10.1155 / 2018 / 1871058$.

[19] S. H. Chio and C. C. Chiang, "Feasibility study using UAV aerial photogrammetry for a boundary verification survey of a digitalized cadastral area in an Urban City of Taiwan," Remote Sens., vol. 12, 
2020, doi: 10.3390/rs12101682.

[20] E. Akturk and A. O. Altunel, "Accuracy assesment of a low-cost UAV derived digital elevation model (DEM) in a highly broken and vegetated terrain," Meas. J. Int. Meas. Confed., vol. 136, no. December, pp. 382-386, 2019, doi: 10.1016/j.measurement.2018.12.101.

[21] M. Alatas, S. Budiastuti, T. Gunawan, P. Setyono, J. Burlakovs, and E. Yandri, "The Identification of Microhydro Power Plants Potential in Irrigation Areas Based on Unmanned Air Vehicle (UAV) Image Processing," E3S Web Conf. ICoRER 2019, vol. 190, no. 00024, 2020.

[22] S. K. Gupta and D. P. Shukla, "Application of drone for landslide mapping, dimension estimation and its $3 \mathrm{D}$ reconstruction," J. Indian Soc. Remote Sens., vol. 46, no. 3, 2018, doi: 10.1007/s12524-0170727-1.

[23] G. Fernandes, L. L. Gomes, and L. E. Brandão, “A risk-hedging tool for hydro power plants," Renew. Sustain. Energy Rev., vol. 90, no. March, pp. 370-378, 2018, doi: 10.1016/j.rser.2018.03.081.

[24] X. Cai, F. Ye, and F. Gholinia, "Application of artificial neural network and Soil and Water Assessment Tools in evaluating power generation of small hydropower stations," Energy Reports, vol. 6, pp. 2106-2118, 2020, doi: 10.1016/j.egyr.2020.08.010.

[25] A. Kuriqi, A. . Pinherio, A. Sordo-Ward, and L. Garrote, "Trade-off between environmental flow policy and run-of-river hydropower generation in Mediterranean climate," Eur. Water, vol. 60, no. July, pp. 123-130, 2017.

[26] A. I. Requena, F. Chebana, and T. B. M. J. Ouarda, "A functional framework for flow-duration-curve and daily streamflow estimation at ungauged sites," Adv. Water Resour., vol. 113, pp. 328-340, 2018, doi: 10.1016/j.advwatres.2018.01.019.
[27] S. Barbarelli, M. Amelio, G. Florio, and N. M. Scornaienchi, "Procedure Selecting Pumps Running as Turbines in Micro Hydro Plants," Energy Procedia, vol. 126, pp. 549-556, 2017, doi: 10.1016/j.egypro.2017.08.282

[28] E. Quaranta and R. Revelli, "Gravity water wheels as a micro hydropower energy source: A review based on historic data, design methods, efficiencies and modern optimizations," Renew. Sustain. Energy Rev., vol. 97, no. August, pp. 414-427, 2018, doi: 10.1016/j.rser.2018.08.033.

[29] R. K. Mohanta, T. R. Chelliah, S. Allamsetty, A. Akula, and R. Ghosh, "Sources of vibration and their treatment in hydro power stations-A review," Eng. Sci. Technol. an Int. J., 2016, doi: 10.1016/j.jestch.2016.11.004.

[30] J. Butchers, S. Williamson, J. Booker, A. Tran, P. B. Karki, and B. Gautam, "Understanding sustainable operation of micro-hydropower: a field study in Nepal," Energy Sustain. Dev., vol. 57, pp. 12-21, 2020 , doi: 10.1016/j.esd.2020.04.007.

[31] J. M. Ngowi, L. Bångens, and E. O. Ahlgren, "Benefits and challenges to productive use of off-grid rural electrification: The case of minihydropower in Bulongwa-Tanzania," Energy Sustain. Dev., vol. 53, pp. 97-103, 2019, doi: 10.1016/j.esd.2019.10.001.

[32] A. López-González, L. Ferrer-Martí, and B. Domenech, "Long-term sustainability assessment of micro-hydro projects: Case studies from Venezuela," Energy Policy, vol. 131, pp. 120-130, 2019, doi: 10.1016/j.enpol.2019.04.030.

[33] Erinofiardi et al., "A review on micro hydropower in Indonesia," Energy Procedia, vol. 110, no. December 2016, pp. 316-321, 2017 doi: 10.1016/j.egypro.2017.03.146. 